\title{
Phytochemical analysis of hydroethanolic extract of Turnera diffusa Willd and evaluation of its effects on astrocyte cell death
}

\author{
Análise fitoquímica do extrato hidroetanólico de Turnera diffusa Willd \\ e avaliação de seus efeitos na morte de astrócitos
}

\author{
Andréia Gomes Bezerra ${ }^{1}$, Giuseppina Negri ${ }^{1}$, Joaquim Maurício Duarte-Almeida ${ }^{2}$,
} Soraya Soubhi Smaili ${ }^{1}$, Elisaldo Araújo Carlini ${ }^{1}$

\begin{abstract}
Objective: To evaluate the phytochemical composition of hydroethanolic extracts from powdered aerial parts of Turnera diffusa Willd (Turneraceae; T. diffusa), as well as its toxicity in astrocytes. Methods: Chemical analyses of hydroethanolic extract from powdered aerial parts of $T$. diffusa were carried out using HPLC-DAD-ESI-MS/MS. In vitro assays using astrocytes culture were performed to evaluate cell death. Results: Flavone-C, 0-diglycosides, such as, luteolin-8-C-[6-deoxy-2-0-rhamnosyl]-xylo-hexos3-uloside, apigenin-8-C-[6-deoxy-2-0-rhamnosyl]-xylo-hexos-3-uloside and apigenin-7-0-6"-p-coumaroylglucoside were the main compounds found in this hydroethanolic extract. Concentration time-effect demonstrated the toxicity of this extract at a concentration of $1,000 \mu \mathrm{g} / \mathrm{mL}$ in astrocyte culture, after 6 and 24 hours of incubation. Conclusion: In phytochemical analyses, important antioxidants (mainly flavonoids) were observed. $T$. diffusa extracts presented cytotoxic effect in high concentrations, leading to increased cell death in astrocyte culture.
\end{abstract}

Keywords: Cognition/drug effects; Plant extracts/toxicity; Protective agents/toxicity; Antioxidants; Cell death/drug effects

\section{RESUMO}

Objetivo: Avaliar a composição fitoquímica do extrato hidroetanólico das partes aéreas de Turnera diffusa Willd (Turneraceae; T. diffusa) e sua toxicidade em astrócitos. Métodos: Análises químicas do extrato hidroetanólico de partes aéreas de T. diffusa foram feitas por HPLC-DADESI-MS/MS. Os ensaios in vitro utilizaram culturas de astrócitos para avaliar morte celular. Resultados: Flavonas-C, 0-diglicosídeos, como, luteolina-8-C-[6-deoxi-2-0-raminosil]-xilo-hexos-3-ulosideo, apigenina-
8-C-[6-deoxi-2-0-raminosil]-xilo-hexos-3-ulosideo e apigenina-7-0-6"$p$-cumaroilglucosídeo foram os principais constituintes encontrados neste extrato hidroetanólico. Uma curva tempo-concentração demonstrou toxicidade desse extrato na concentração de $1.000 \mu \mathrm{g} / \mathrm{mL}$, na cultura de astrócitos após 6 e 24 horas de incubação. Conclusão: Nas análises fitoquímicas, importantes antioxidantes, sobretudo flavonoides, foram observados. Extratos de T. diffusa apresentaram efeitos citotóxicos em altas concentrações, ocasionando aumento de morte celular em cultura de astrócitos.

Descritores: Cognição/efeito de drogas; Extratos vegetais/toxicidade; Substâncias protetoras/toxicidade; Antioxidantes; Morte celular/efeitos de drogas

\section{INTRODUCTION}

The genus Turnera (Turneraceae) encompasses 135 species from tropical parts of the Americas and Africa. ${ }^{(1)}$ Turnera diffusa Wild ex Schult (T. diffusa), known in Brazil as "damiana", is the most important Turnera species, which has many applications in traditional medicine. This species is found in Mexico, Central America, the Caribbean Islands and parts of South America. It has several traditional uses as an aphrodisiac, for hepatic symptoms, depression, anxiety and neurosis, as well as expectorant, stimulant and tonic; being also used to flavor desserts and beverages. ${ }^{(2,3)}$

\footnotetext{
Universidade Federal de São Paulo, São Paulo, SP, Brazil.

2 Universidade Federal de São João del-Rei, Divinópolis, MG, Brazil.

Corresponding author: Andréia Gomes Bezerra - Rua Napoleão de Barros, 925 - Vila Clementino - Zip code: 04024-002 - São Paulo, SP, Brazil - Phone: (55 11) 2149-0155 - E-mail: andreia.bzr@gmail.com Received on: May 16, 2015 - Accepted on: Jan 13, 2016
} 
Previous works have analyzed T. diffusa from a phytochemical perspective. In general, the aerial parts (stems and leaves) of this species show good antioxidant activity, similar to that exhibited by quercetin. ${ }^{(4)}$ Moreover, alkaloids, cyanogenic glycosides, flavonoids, and volatile oils are the main classes of phytoconstituents found in Turnera genus. ${ }^{(2,4-8)}$

Potential therapeutic uses of $T$. diffusa have been described in previous studies, including gastroprotective, anti-ultra violet radiation and anti-oncogenic effects, ${ }^{(9-12)}$ all of them depending in some extent of $T$. diffusa's antioxidant properties. Despite of these potential positive effects, none study evaluated the toxicity threshold of $T$. diffusa. Cell death (which includes apoptosis and necrosis) is closely related to oxidative stress; ${ }^{(13,14)}$ however, up to now none report has been performed in order to evaluate the effects of $T$. diffusa on cell death.

\section{OBJECTIVE}

To evaluate the phytochemical composition of hydroethanolic extracts from powdered aerial parts of Turnera diffusa Willd, as well as its toxicity in astrocytes.

\section{METHODS}

\section{Plant material}

Powdered aerial parts of $T$. diffusa were obtained commercially, from Quimer Ltda and this botanical material was deposited at Herboteca Carlos Stellfeld in the Universidade Federal do Paraná (UFPR), under number $340 .^{(5)}$

\section{Drugs and preparation of extracts}

Quercetin, apigenin, kaempferol and luteolin were purchased from Sigma-Aldrich Chemical Co. (Saint Louis, MO, USA). The solutions of these standards $(100 \mu \mathrm{g} / \mathrm{mL}$ in ethanol) were prepared and analyzed by high-performance liquid chromatography coupled to diode-array detector (HPLC-DAD), in order to carry out the optimization of chromatographic conditions for analysis of hidroethanolic extract. HPLC-grade methanol was purchased from Merck (Darmstadt, Germany). HPLC-grade water was prepared from distilled water using a Milli-Q system (Millipore, Waters, Milford, MA, USA). Powdered aerial parts from $T$. diffusa, (100g) were extracted with 1L of hydroethanolic solution $(50 \%, \mathrm{v} / \mathrm{v})$ by turbolysis, as described by Bezerra et al. ${ }^{(5)}$ The solutions were filtered, concentrated under reduced pressure in a rotary evaporator, lyophilized and stored in amber flasks at $5^{\circ} \mathrm{C}$.

High-performance liquid chromatography coupled to diode-array detector and electrospray ionization - mass spectrometry/mass spectrometry analysis of hydroethanolic extract.

The lyophilized extract $(8 \mathrm{mg})$ was dissolved in $3 \mathrm{~mL}$ of methanol: water $(20: 80, \mathrm{v} / \mathrm{v})$ and filtered through a $0.45 \mu \mathrm{m}$ filter (German Sciences, Tokyo, Japan). An aliquot $31.2 \mu \mathrm{L}$ of lyophilized extract was injected into the HPLC system. All solvents were of HPLC grade and were filtered using a solvent filtration apparatus. A DAD SPD-M10AVP (Shimadzu) equipped with a photodiode array detector was coupled to an Esquire 3000 Plus mass spectrometer (Bruker Daltonics) with an electrospray ionization (ESI) source and ion trap mass analyzer. Double in-line detection was carried out in the DAD, using 270 and $340 \mathrm{~nm}$ as preferred wavelengths, and in-line ultraviolet spectrum were recorded in the range of 200 to $400 \mathrm{~nm}$. A reverse phase C18 Zorbax - 5B - RP-18 (Hewlett Packard) column $(4.6 \times 250 \mathrm{~mm}, 5 \mu \mathrm{m})$ with a precolumn guard filter was employed for separation of constituents. The mobile phases consisted of A ( $0.1 \%$ aq. formic acid) and B (methanol). The elution gradient was: zero minute $20 \% \mathrm{~B}$ in $\mathrm{A} ; 10$ minutes $-30 \% \mathrm{~B}$ in $\mathrm{A} ; 20$ minutes $-50 \%$ $\mathrm{B}$ in $\mathrm{A} ; 30$ minutes $-70 \% \mathrm{~B}$ in $\mathrm{A} ; 40$ minutes $-90 \% \mathrm{~B}$ in $\mathrm{A}$; 45 minutes $-40 \% \mathrm{~B}$ in $\mathrm{A}$; and 50 minutes $-20 \%$ $\mathrm{B}$ in A. The flow rate was kept constant at $0.5 \mathrm{~mL} \cdot \mathrm{min}^{-1}$, and the temperature of the column was maintained at $28^{\circ} \mathrm{C}$. The mass spectrometry (MS) analysis was carried out using ESI at atmospheric pressure in positive and negative ion modes. The ionization conditions were adjusted as follows: ion source electrospray voltage of $-40 \mathrm{~V}$, capillary voltage of $4,500 \mathrm{~V}$ and capillary temperature of $325^{\circ} \mathrm{C}$. Helium was used as the collision gas and nitrogen as the nebulizing gas. Nebulization was aided with a coaxial nitrogen sheath gas provided at a pressure of $27 \mathrm{psi}$. Desolvation was assisted using a counter current nitrogen flow set at a flux of 7.0L.min ${ }^{-1}$. Full scan mass acquisitions were performed in both negative and positive ion modes by scanning the $\mathrm{m} / \mathrm{z}$ range from 100 to 1,000 mass units. Collision induced dissociation (CID) spectra were obtained in the ion trap using helium as the collision gas, with voltage ramping cycles from 0.5 to $1.3 \mathrm{~V}$. Characterization of constituents was carried out based in UV and mass spectra data, together with fragmentation profiles obtained through mass spectrometry/mass spectrometry (MS/MS spectra), which were compared with literature data and also based on constituents reported for this specie in another studies. 


\section{Culture of astrocytes of rat cortex}

A culture of astrocytes was obtained from the cortex of rats 3 days old, as described previously by Smaili and Russell. ${ }^{(15)}$ The animals were obtained from Instituto Nacional de Farmacologia of Universidade Federal de São Paulo (UNIFESP). This project was approved by the Ethics Committee of UNIFESP (0464/05).

The cells were grown in low glucose Dulbecco's modified Eagle's medium containing $10 \%$ fetal bovine serum, $0.1 \%$ fungizone, $1 \%$ penicillin/streptomycin, $1 \mathrm{mM}$ sodium pyruvate and $4 \mathrm{mM}$ L-glutamine in $5 \%$ $\mathrm{CO}_{2} / 95 \%$ air. The media was replaced every other day until confluency (after 8 to 14 days). When confluency was reached, the removal of the cells from the flasks was performed by trypsinization. For that, trypsin/EDTA $(0.25 \%)$ was added to the flasks for 5 minutes, at $37^{\circ} \mathrm{C}$, followed by enzyme inactivation by DNAse $(10 \mathrm{mM})$ and centrifugation $\left(2,500 \mathrm{rpm}, 10\right.$ minutes, $\left.25^{\circ} \mathrm{C}\right)$. Cells were then suspended in culture medium. After trypsinization, $10 \mu \mathrm{L}$ of the suspension were quantified using a Neubauer chamber, an inverse microscope and a cell counter. The total amount of cells was of $72 \times 10^{4}$ cell $/ \mathrm{mL}$. After dilutions, the cells were platted in a 24 wells plate, for a final concentration of 18,000 cells/well, which allowed cells observation and counting.

\section{Evaluation of cell death using Hoechst 33342}

Cell morphology was evaluated by fluorescence microscopy following Hoechst 33342 staining. The hydroethanolic extract from $T$. diffusa was added to the cells at initial concentrations of 10,100 and $1,000 \mu \mathrm{g} / \mathrm{mL}$ and were evaluated after 6,24 and 48 hours of incubation to assess the toxicity of the extracts. Control cells did not receive any treatment. These cells were also used in other experiments not reported here.

After a separate incubation, cells were washed with buffer and stained with Hoechst $33342(1 \mu \mathrm{g} / \mathrm{mL})$ for 15 minutes, at room temperature, in the dark. Cell death was identified by some characteristics, such as nuclear condensation, formation of membrane blebs and apoptotic bodies. Fragmented nuclei or nuclei with condensed chromatin were counted and the percentage of these nuclei relative to the total nuclei observed in each field was calculated. The results at each concentration and incubation time were determined from, at least, four independent experiments performed in triplicate. ${ }^{(16)}$

\section{Statistical analysis}

Data analysis was performed using One-Way Analysis Of Variance (ANOVA) followed by Duncan's test when appropriate. The results are expressed as the mean \pm standard error (SE) of the mean and a significance level of $5 \%$ was adopted.

\section{RESULTS}

\section{Phytochemical analyses}

Table 1 list the retention times (Rt), MS spectral data and wavelength of maximal absorption $\left(\lambda_{\max }\right)$ for the chemical constituents found in this hydroethanolic extracts. The characterization of constituents was achieved, through MS spectral data reported previously for compounds found in this plant or other plant materials. The total ion current chromatogram obtained in ESI-MS negative ionization mode is shown in figure 1.

Table 1. Retention times, mass spectral data and wavelength of maximal absorption $\left(\lambda_{\max }\right)$ for the chemical constituents found in hydroethanolic extracts from Turnera diffusa

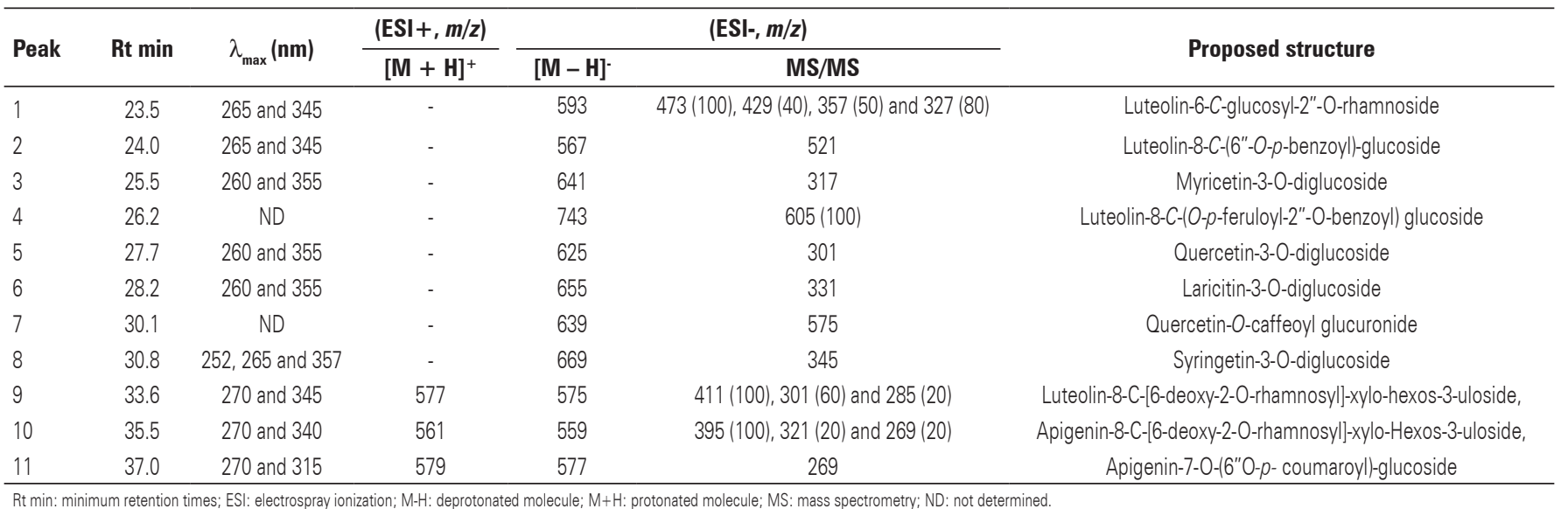




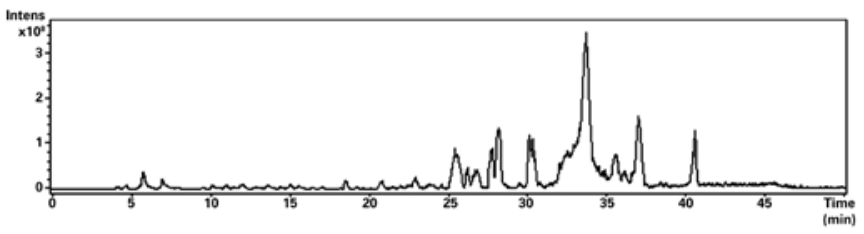

Figure 1. Total ion current chromatogram obtained through electrospray ionization

Mass spectrum analysis in negative ionization mode from hydroethanolic extract from $T$. diffusa is showed in figure 1. Peak number are correspondent to the compounds disclosed at table 1.

The main constituents found in $T$. diffusa were flavonoids, a mixture of flavone- $C, O$-diglycosides, $C$-glycosyl flavone acylated with aromatic acids and flavonols 3-O-diglucosides.

Compounds 1, 2, 9 and 10 exhibited UV spectra characteristic of flavones. The ESI-MS spectrum of compound 9, the main constituent found in this extract, showed deprotonated and protonated molecule at $\mathrm{m} / z 575$ and $\mathrm{m} / \mathrm{z} 577$, respectively. After MS/MS experiments, fragment ion at $\mathrm{m} / z 411$ was abundantly produced, which correspond to the loss of 164 mass units, sugar (rhamnose) and water moieties $(146+18)$, characteristic of a bond between a sugar (rhamnose) and a non-phenolic hydroxyl group, most likely at the 2 "-O position of the other sugar moiety, indicating an $O$-glycosylation with a deoxyhexose (rhamnose). This fragmentation pattern in negative ionization mode was typical of an $O$, C-diglycosylflavone. An unusual fragment ion occurred at $\mathrm{m} / z 301(60 \%)$, together with the fragment ion corresponding to the aglycone luteolin at $\mathrm{m} / z 285(20 \%)$.

Compound 10 showed deprotonated and protonated molecules at $\mathrm{m} / \mathrm{z} 559$ and $\mathrm{m} / \mathrm{z} 561$, respectively, in the ESI-MS spectra. The MS/MS spectrum of the precursor ion at $\mathrm{m} / z 559$ showed abundant fragment ion at $\mathrm{m} / \mathrm{z}$ 395 , indicating 2"-O-glycosylation with deoxyhexose (rhamnose), and fragment ion at $\mathrm{m} / z 269$ (20\%), indicating apigenin as aglycone.

The ESI-MS spectrum of compound 2 showed deprotonated molecule at $\mathrm{m} / z 567$, which after MS/MS experiments produced fragment ion at $\mathrm{m} / z$ 521, corresponding to the loss of 46 mass units [ $\mathrm{HCOOH}$ ], which could occur through decarboxylation of a carboxylic acid from benzoic acid moiety. The sugar moiety linked to luteolin could be glucose substituted with benzoic acid on the hydroxyl group in position $6 "-O$ of glucose because, in this position, the cleavage of benzoyl group was more difficult. Compound 2 was tentatively identified as luteolin-8-C-(6"-O-p-benzoyl) glucoside.
The ESI-MS spectrum of compound 4 exhibited deprotonated molecule at $\mathrm{m} / z 743$. The molecular mass of compound 4 indicated the presence an additional feruloyl moiety (176 mass units) in its structure, when compared to compound 2. The exact location of the acyl group on the glycosidic moiety was difficult to determine, just based on MS. However, the MS/MS spectrum of the precursor ion at $\mathrm{m} / z 743$ showed abundant fragment ion at $\mathrm{m} / z 605$, corresponding to the loss of 137 mass units (hydroxybenzoic acid moiety), what could indicated that the hydroxybenzoic acid was attached to glucose at 2"-O-position. Compound 4 was tentatively assigned as luteolin-8-C-(O-p-feruloyl-2"-Obenzoyl)-glucoside.

For compound 1, the ESI-MS spectrum showed deprotonated molecule at $\mathrm{m} / z$ 593, which after MS/MS experiments produced abundant fragment ion at $\mathrm{m} / z 473$, characteristic of the presence of hexose as $C$-glycosylated sugar moiety. The fragment ions at $\mathrm{m} / z 357(\mathrm{~A}+71)$ and $\mathrm{m} / z 327(\mathrm{~A}+41)$ were characteristic of flavones- $O, C$-diglycosides and suggested luteolin as the aglycone.

In the Rt 25.5 minutes a co-elution of two compounds was observed, compound 3 and another constituent in minor content, that exhibited deprotonated molecular ion at $\mathrm{m} / \mathrm{z} 593$ and was tentatively characterized as quercetin dirhamnoside. Compounds 3, 5, 6 and 8 exhibited UV spectra characteristic of flavonols and their ESI-MS spectra exhibited deprotonated molecules at $\mathrm{m} / \mathrm{z}$ 641, 625, 655 and 669, respectively. The ESI-MS/MS spectra of these compounds in negative ionization mode showed the loss of 324 mass units, indicating the presence of two hexoses (glucoses), probably linked at 3-O-position of aglycone. Thus, compound 3 was suggested as myricetin-3-O-diglucoside, compound 5 as quercetin-3- $O$-diglucoside, compound 6 as laricitin3-O-diglucoside and compound 8 as syringetin-3-Odiglucoside.

The MS spectrum of compound 7 showed deprotonated molecule at $\mathrm{m} / z$ 639, and after MS/MS experiments exhibited abundant fragment ion at $\mathrm{m} / \mathrm{z}$ 575 , corresponding to the loss of 64 mass units, which could be attributed to a combined loss of $\mathrm{COOH}$ and $\mathrm{OH}$ groups. According to MS spectral data compound 7 was suggested as quercetin caffeoyl glucuronide.

The UV maximum absorption at $312 \mathrm{~nm}$ and the higher Rt indicated that compound 11 was a flavonoid glycoside esterified with aromatic acids. The ESI-MS spectra exhibited protonated and deprotonated molecules at $\mathrm{m} / z 579$ and 577, respectively. The MS/MS spectrum of the precursor ion at $\mathrm{m} / z 577$ showed abundant fragment ion at $\mathrm{m} / z 269$, which was attributed to the 
loss of 308 mass units (glucose with a $p$-coumaroyl moiety), and indicated apigenin as aglycone.

\section{Evaluation of cell death using Hoechst $\mathbf{3 3 3 4 2}$}

ANOVA detected a significant increase on the percentage of dead cells after incubation for 6 hours, with the $T$. diffusa extract, at a concentration of $1,000 \mu \mathrm{g} / \mathrm{mL}$, when compared to the control group and with lower concentrations $\left[\mathrm{F}_{(3,32)}=3.03 ; \mathrm{p}<0.05\right]$ (Figure 2). This effect persisted in cells evaluated after 24 hours of incubation $\left[\mathrm{F}_{(3,32)}=5.19 ; \mathrm{p}<0.05\right]$, but only when compared with control group and with concentration of $10 \mu \mathrm{g} / \mathrm{mL}$ (Duncan; $\mathrm{p}<0.01$ ). Figure 3 presents an example of Hoechst 33342 staining, showing both live and death astrocyte nuclei.

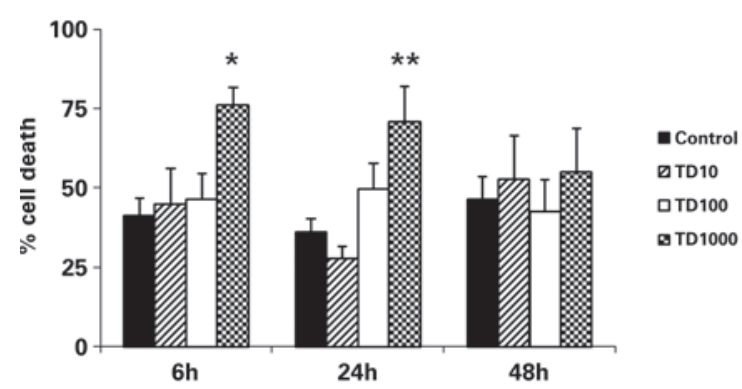

The data represent the mean \pm SEM of four independent experiments done in triplicate. Analysis of Variance/Duncan: ${ }^{*} p<0.05$ (compared to all other groups, at 6 hours); ${ }^{* *} p<0.05$ (compared to the control group and the group TD10, at 24 hours).

Figure 2. Dead cells after incubation for 6, 24 and 48 hours, at doses of 10, 100 and $1,000 \mu \mathrm{g} / \mathrm{mL}$ Turnera diffusa extract

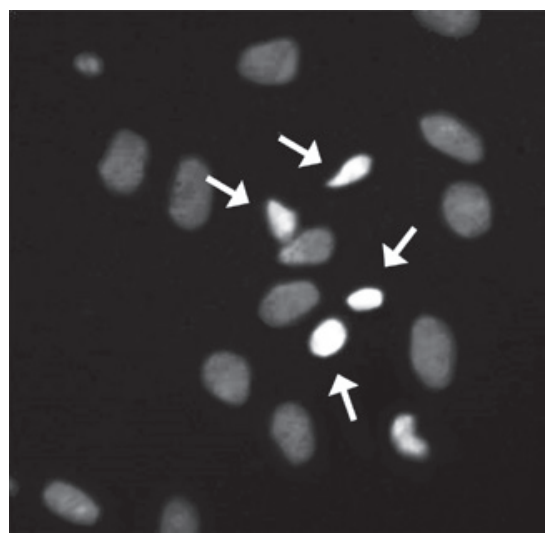

Figure 3. Nuclei of astrocytes marked with Hoechst 33342 and examined under a fluorescence microscope. Arrows identify the nuclei of dead cells and the remaining nuclei represent live cells

\section{DISCUSSION}

The main constituents found in this extract were flavonoids (flavones and flavonols glycosides). Flavonols and flavones were distinguished by their UV spectra with maxima at 255/370 and 268/340nm, respectively, and also fragmentation pattern of C-glycosyl and O-glycosyl flavonoids. Flavonoids C-glycosides are stable towards acid hydrolysis, due to glycosidic C-C bond and the main fragmentations take place in the sugar, which possess the weakest bonds. ${ }^{(17,18)}$ Flavonoid $O$-glycosides are bounded to a sugar with formation of an acid labile glycosidic O-C bond. Fragmentation of these flavonoids involves the cleavage at the glycosidic$O$-linkage with a concomitant $\mathrm{H}$-rearrangement leading to the elimination of the saccharide residue. ${ }^{(18-21)}$ For flavonols, the $3-\mathrm{OH}$ and $7-\mathrm{OH}$ positions are regular glycosilation sites. ${ }^{(22)}$

According to MS spectral data reported by Ferreres et al. ${ }^{(23)}$ and Figueirinha et al., ${ }^{(24)}$ compound 9 found in the present study was characterized as luteolin8-C-[6-deoxy-2-O-rhamnosyl]-xylo-hexos-3-uloside, which was also found by Zhao et al., ${ }^{(7,8)}$ in $T$. diffusa, and by Figueirinha et al.,(24) in Cymbopogon citratus. Conforming to MS spectral data reported by Ferreres et al., ${ }^{(23)}$ compound 10 was identified as apigenin-8C-[6-deoxy-2-O-rhamnosyl]-xylo-hexos-3-uloside, which was reported in Passiflora edulis. ${ }^{(23)}$ Arbutin (4-hydroxyphenyl $\beta$-D-glucoside) and $p$-coumaroyl glycosides were reported in this species. ${ }^{(7,8)}$

In consonance to MS data reported by Ferreres et al., ${ }^{(17,23)}$ compound 1 was tentatively identified as luteolin6-C-glucosyl-2"-O-rhamnoside. The fragment ion at $\mathrm{m} / z 429$ attributed to the loss of rhamnose and water moieties indicated $\mathrm{O}$-glycosylation with a deoxyhexose (rhamnose) at the 2"-O position of glucose. ${ }^{(23)}$

Regarding compounds 3, 5, 6 and 8, Fracassetti et al. ${ }^{(25)}$ discuss that flavonol-O-glycoside with a free hydroxyl at 3-O position show a UV band I maximum at $374 \mathrm{~nm}$, while flavonol with a blocked hydroxyl at 3-O position of aglycone showed UV band I maximum at $356 \mathrm{~nm}$. The introduction of methyl groups into the flavonols increases the $\mathrm{Rt},{ }^{(18)}$ and the elution order was found to be myricetin $(\mathrm{m} / z$ 317), quercetin $(\mathrm{m} / z$ 301), laricitin $(\mathrm{m} / z$ 331) and syringetin $(\mathrm{m} / z$ 345). Laricitin3-O-diglucoside and syringetin-3-O-diglucoside were reported in $T$. diffusa by Zhao et al. ${ }^{(7,8)}$ and Szewczyk and Zidorn. ${ }^{(2)}$

Generally, flavonoid glycosides esterified with aromatic acids have longer Rt on RP-HPLC columns than diglycosides and monoglycosides and its UV spectra exhibit an intense band I (approximately 330nm) and a small band II at $270 \mathrm{~nm}$, resulting from the UV absorption overlap of the flavonoid and the cinnamoyl acid. ${ }^{(18)}$ The predominant site of bonding of the acyl groups is usually the 6"-position of hexose, although 
other positions should not be excluded.(18) Compound 11 was identified as apigenin-7-O-(6"-O-p-coumaroyl) glucoside, which was found in high concentration in this species by Camargo and Vilegas. ${ }^{(26)}$

Some studies had shown that flavonoids from diverse herbal medicines have significant effects in different developmental stages of nervous systems, including neuronal stem cell differentiation, neurite outgrowth, and neuronal plasticity. ${ }^{(27,28)}$ Polyphenols and flavonoids present in Ocimum sanctum hydroalcoholic extract ameliorated $\mathrm{H}_{2} \mathrm{O}_{2}$ induced neuronal damage through its antioxidant defense mechanism, exhibiting potential to be used to treat oxidative stress mediated neuronal disorders. ${ }^{(29)}$ The neuroprotective actions of flavonoids are believed to occur through direct interactions with cellular cascades, yielding expression of neuroprotective and neuromodulatory proteins that promote neurogenesis, neuronal function and brain connectivity, and also through blood-flow improvement and angiogenesis in the brain and sensory systems. ${ }^{(30)}$

Previous studies demonstrated neuroprotective effects by luteolin, through increasing the neuronal viability, reducing the number of apoptotic cells ${ }^{(31)}$ and reducing ischemia-induced cellular injury. ${ }^{(32)}$ The prevention of oxidative stress, had been attributed to flavonoids, which can also modulate both enzymes and receptors activities, acting as multi-target botanical therapeutics or drugs. ${ }^{(33)}$ However, in certain concentrations, flavonoids can also act as pro-oxidants, depleting the nuclear antioxidant defense systems and leading to oxidative DNA damage. ${ }^{(34)}$ This finding is in accordance to our results that showed that high concentrations of $T$. diffusa could cause cell death in astrocytes.

The $T$. diffusa extract demonstrated toxicity at a concentration of $1,000 \mu \mathrm{g} / \mathrm{mL}$ after both 6 and 24 hours of incubation. However, concentrations of 10 and $100 \mu \mathrm{g} / \mathrm{mL}$ of extract showed similar effects as those observed in the control group, which underscores the low cellular toxicity of these doses during this period. Thus, one may note that $T$. diffusa has a dose-dependent toxicity. The toxicity threshold for this plant lies between 100 and $1,000 \mu \mathrm{g} / \mathrm{mL}$, for astrocyte death. This dose-dependent relationship and this estimative for a toxicity threshold may explain, to a certain extent, the opposition in anti- and pro-oxidative effects.

It was expected that after 48 hours of incubation, $1,000 \mu \mathrm{g} / \mathrm{mL}$ concentrations of the $T$. diffusa extract would also decrease the viability of astrocytes, but the results indicated that the cells did not differ from the control. This result may have occurred because the control cells began to run out of nutrients after 48 hours in unchanged medium, leading to a loss of adherence and natural death.

For the proper assessment of these results, some limitations must be taken into account. First, one must bear in mind that, despite being a widely used method, Hoechst 33342 is a highly unspecific technique. Thus, it is not possible to determine which is the real type or source of the cell death observed in these experiments. In other words, it is not possible to determine if cell death was caused by apoptosis, necrosis or some other phenomena. Another important caveat relies on the establishment of a toxicity threshold. In accordance to our experiments, it is possible to affirm that the toxicity threshold lies somewhere between 100 and $1,000 \mu \mathrm{g} / \mathrm{mL}$. This is a quite large interval, and the lack of other experiments evaluating the toxic effects of $T$. diffusa prevents the establishment of a more precise toxicity level. Moreover, one must bear in mind that this toxicity level applies exclusively for cell death observed in astrocytes. Any other type of toxic effect, as well as effects in other types of cells and tissues, may have their own toxic levels. On the other hand, it can be assumed that further studies on potential therapeutic effects of T. diffusa may focus on doses lower than $100 \mu \mathrm{g} / \mathrm{mL}$. As final caveat relies the phytochemical profile observed in the current experiment. As in great part of the experiments carried out with medicinal plants, the extracted compounds depend upon environmental factors (planting site, soil characteristics, temperature and humidity, among others), harvest and postharvest procedures (drying, milling and storage) and extraction methods (different techniques, solvents and concentrations). Thus, the acquired results should be contextualized to the characteristics of this experiment. It is highly likely that other experiments using T. diffusa extract present similar phytochemical profile, but some variations are expected, reason why phytochemical analysis are always useful in this kind of experiments.

\section{CONCLUSION}

Turnera diffusa Willd (Turneraceae) is used by Brazilian population and the evaluation of its efficacy have value under ethnopharmacological point of view. Chemical analysis revealed the presence of flavone-C, O-diglycosides, such as luteolin-8-C-[6-deoxy-2-Orhamnosyl]-xylo-hexos-3-uloside, apigenin-8-C-[6-deoxy2-O-rhamnosyl]-xylo-hexos-3-uloside and apigenin-7O-6"-p-coumaroylglucoside in high concentrations in this hydroethanolic extract. Hydroethanolic extract of Turnera diffusa presented cytotoxic activity and increased 
the percentage of astrocyte death only at $1,000 \mu \mathrm{g} / \mathrm{mL}$, both on the conditions of 6 and 24 hours of exposure.

\section{ACKNOWLEDGMENTS}

This work was supported by Associação Fundo de Incentivo à Psicofarmacologia (AFIP), Centro Brasileiro de Informações sobre Drogas Psicotrópicas (CEBRID), Coordenação de Aperfeiçoamento de Pessoal de Nível Superior (CAPES) and Fundação de Amparo à Pesquisa do Estado de São Paulo (FAPESP).

\section{REFERENCES}

1. Thulin M, Razafimandimbison SG, Chafe P, Heidari N, Kool A, Shore JS. Phylogeny of the Turneraceae clade (Passifloraceae s.l.): Trans-Atlantic disjunctions and two new genera in Africa. Taxon. 2012;61:(2)308-23.

2. Szewczyk K, Zidorn C. Ethnobotany, phytochemistry, and bioactivity of the genus Turnera (Passifloraceae) with a focus on damiana--Turnera diffusa. J Ethnopharmacol. 2014;152(3):424-43. Review.

3. Mendes FR. Tonic, fortifier and aphrodisiac: adaptogens in the Brazilian folk medicine. Braz J Pharmacogn. 2011;21(4):754-63. Review.

4. Lucio-Gutiérrez JR, Garza-Juárez A, Coello J, Maspoch S, Salazar-Cavazos ML, Salazar-Aranda $R$, et al. Multi-wavelength high-performance liquid chromatographic fingerprints and chemometrics to predict the antioxidant activity of Turnera diffusa as part of its quality control. J Chromatogr A. 2012; 1235:68-76

5. Bezerra AG, Mendes FR, Tabach R, Carlini EA. Effects of a hydroalcoholic extract of Turnera diffusa Willd. Ex Schult., Turneraceae, in tests for adaptogenic activity. Braz J Pharmacogn. 2011;21(1):121-7.

6. Kumar S, Taneja R, Sharma A. The genus turnera.: A review update. Pharm Biol. 2005;43(5):383-91.

7. Zhao J, Pawar RS, Ali Z, Khan IA. Phytochemical investigation of Turnera diffusa. J Nat Prod. 2007;70(2):289-92.

8. Zhao J, Dasmahapatra AK, Khan SI, Khan IA. Anti-aromatase activity of the constituents from damiana (Turnera diffusa). J Ethnopharmacol. 2008; 120(3):387-93.

9. Soriano-Melgar Lde A, Alcaraz-Meléndez L, Méndez-Rodríguez LC, Puente ME, Rivera-Cabrera F, Zenteno-Savín T. Antioxidant responses of damiana (Turnera diffusa Willd) to exposure to artificial ultraviolet (UV) radiation in an in vitro model; part I; UV-C radiation. Nutr Hosp. 2014;29(5):1109-15

10. Soriano-Melgar Lde A, Alcaraz-Meléndez L, Méndez-Rodríguez LC, Puente ME, Rivera-Cabrera F, Zenteno-Savín T. Antioxidant responses of damiana (Turnera diffusa Willd) to exposure to artificial ultraviolet (UV) radiation in an in vitro model; part ii; UV-B radiation. Nutr Hosp. 2014;29(5):1116-22.

11. Avelino-Flores Mdel C, Cruz-López Mdel C, Jiménez-Montejo FE, Reyes-Leyva J. Cytotoxic activity of the methanolic extract of Turnera diffusa Willd on breast cancer cells. J Med Food. 2015;18(3):299-305.

12. Taha MM, Salga MS, Ali HM, Abdulla MA, Abdelwahab SI, Hadi AH. Gastroprotective activities of Turnera diffusa Willd. ex Schult. revisited: Role of arbutin. J Ethnopharmacol. 2012;141(1):273-81.

13. Whittemore ER, Loo DT, Cotman CW. Exposure to hydrogen peroxide induces cell death via apoptosis in cultured rat cortical neurons. Neuroreport. 1994; 5(12):1485-8.

14. Chandra J, Samali A, Orrenius S. Triggering and modulation of apoptosis by oxidative stress. Free Radic Biol Med. 2000;29(3-4):323-33. Review.
15. Smaili SS, Russell JT. Permeability transition pore regulates both mitochondrial membrane potential and agonist-evoked $\mathrm{Ca} 2+$ signals in oligodendrocyte progenitors. Cell Calcium. 1999;26(3-4):121-30.

16. Rosenstock TR, Carvalho AC, Jurkiewicz A, Frussa-Filho R, Smaili SS Mitochondrial calcium, oxidative stress and apoptosis in a neurodegenerative disease model induced by 3-nitropropionic acid. J Neurochem. 2004;88(5): 1220-8.

17. Ferreres F, Gil-Izquierdo A, Vinholes J, Silva ST, Valentão P, Andrade PB. Bauhinia forficata Link authenticity using flavonoids profile: relation with their biological properties. Food Chem. 2012;134(2):894-904.

18. Abad-García B, Berrueta LA, Garmón-Lobato S, Gallo B, Vicente F. A general analytical strategy for the characterization of phenolic compounds in fruit juices by high-performance liquid chromatography with diode array detection coupled to electrospray ionization and triple quadrupole mass spectrometry. J Chromatogr A. 2009;1216(28):5398-415.

19. Gouveia SC, Castilho PC. Characterization of phenolic compounds in Helichrysum melaleucum by high-performance liquid chromatography with on-line ultraviolet and mass spectrometry detection. Rapid Commun Mass Spectrom. 2010;24(13):1851-68.

20. Gouveia S, Castilho PC. Characterization of phenolic acid derivatives and flavonoids from different morphological parts of Helichrysum obconicum by a RP-HPLC-DAD-(-)-ESI-MS(n) method. Food Chem. 2011;129(2):333-44.

21. Orhan IE, Senol FS, Ercetin T, Kahraman A, Celep F, Akaydin G, et al. Assessment of anticholinesterase and antioxidant properties of selected sage (Salvia) species with their total phenol and flavonoid contentes. Industrial Crops and Products. 2013;41:21-30.

22. Abad-García B, Garmón-Lobato S, Berrueta LA, Gallo B, Vicente F. On line characterization of 58 phenolic compounds in Citrus fruit juices from Spanish cultivars by high-performance liquid chromatography with photodiode-array detection coupled to electrospray ionization triple quadrupole mass spectrometry. Talanta. 2012:99:213-24.

23. Ferreres F, Sousa C, Valentão P, Andrade PB, Seabra RM, Gil-Izquierdo A. New C-deoxyhexosyl flavones and antioxidant properties of Passiflora edulis leaf extract. J Agric Food Chem. 2007;55(25):10187-93.

24. Figueirinha A, Paranhos A, Pérez-Alonso JJ, Santos-Buelga C, Batista MT. Cymbopogon citratus leaves: Characterization of flavonoids by HPLC-PDAESI/MS/MS and an approach to their potential as a source of bioactive polyphenols. Food Chem. 2008;110(3):718-28.

25. Fracassetti D, Costa C, Moulay L, Tomás-Barberán FA. Ellagic acid derivatives, ellagitannins, proanthocyanidins and other phenolics, vitamin $\mathrm{C}$ and antioxidant capacity of two powder products from camu-camu fruit (Myrciaria dubia). Food Chem. 2013;139(1-4):578-88.

26. Camargo EE, Vilegas W. Quality control of polar extracts from Turnera diffusa Willd. ex Schult., Turneraceae. Braz J Pharmacogn. 2010;20(2):228-32.

27. Liu B, Tang J, Zhang J, Li S, Yuan M, Wang R. Autophagy activation aggravates neuronal injury in the hippocampus of vascular dementia rats. Neural Regen Res. 2014;9(13):1288-96.

28. Xu SL, Zhu KY, Bi CW, Yan L, Men SW, Dong TT, et al. Flavonoids, derived from traditional Chinese medicines, show roles in the differentiation of neurons: possible targets in developing health food products. Birth Defects Res C Embryo Today. 2013;99(4):292-9. Review.

29. Venuprasad MP, Hemanth Kumar K, Khanum F. Neuroprotective effects of hydroalcoholic extract of Ocimum sanctum against $\mathrm{H} 2 \mathrm{O} 2$ induced neuronal cell damage in SH-SY5Y cells via its antioxidative defence mechanism. Neurochem Res. 2013;38(10):2190-200.

30. Sokolov AN, Pavlova MA, Klosterhalfen S, Enck P. Chocolate and the brain: neurobiological impact of cocoa flavanols on cognition and behavior. Neurosci Biobehav Rev. 2013;37(10 Pt 2):2445-53. Review.

31. Zhu L, Bi W, Lu D, Zhang C, Shu X. Luteolin inhibits SH-SY5Y cell apoptosis through suppression of the nuclear transcription factor- $\kappa \mathrm{B}$, mitogen-activated 
protein kinase and protein kinase B pathways in lipopolysaccharidestimulated cocultured BV2 cells. Exp Ther Med. 2014;7(5):1065-70.

32. Zhang YC, Gan FF, Shelar SB, Ng KY, Chew EH. Antioxidant and Nrf2 inducing activities of luteolin, a flavonoid constituent in Ixeris sonchifolia Hance, provide neuroprotective effects against ischemia-induced cellular injury. Food Chem Toxicol. 2013;59:272-80.
33. Grosso C, Valentão P, Ferreres F, Andrade PB. The use of flavonoids in central nervous system disorders. Curr Med Chem. 2013;20(37):4694-719. Review.

34. Cariddi L, Escobar F, Sabini C, Torres C, Reinoso E, Cristofolini A, et al Apoptosis and mutagenicity induction by a characterized aqueous extract of Baccharis articulata (Lam.) Pers. (Asteraceae) on normal cells. Food Chem Toxicol. 2012;50(2):155-61. 